\title{
Nowe narzędzia i technologie komunikacyjne dla osób niepełnosprawnych fizycznie, intelektualnie i społecznie oraz seniorów
}

Tomasz Sahaj

(D) https://orcid.org/0000-0003-0633-7993

Akademia Wychowania Fizycznego

im. Eugeniusza Piaseckiego w Poznaniu 


\title{
Streszczenie
}

W artykule zostały zaprezentowane i omówione wybrane narzędzia i technologie, programy i środowiska internetowe, umożliwiające zapośredniczoną oraz zdalną komunikację, nadzór i opiekę nad ludźmi w wieku senioralnym i nad osobami z niepełnosprawnościami fizycznymi, intelektualnymi oraz społecznymi. Niektóre z tych rozwiązań - jak teleopieka - nabrały szczególnego znaczenia w dobie pandemii COVID-19, który w 2020 r. dwukrotnie spowodował izolację społeczną i lockdown, wymuszając komunikację, edukację i pracę zdalną. Omawiane w tekście rozwiązania są różnej proweniencji: od animowanych przez pojedynczych aktorów społecznych, instytucje komercyjne lub pomocowe organizacje społeczne, aż po kompleksowe rozwiązania programów rządowych. Wszystkie łączy to, że wspierając osoby społecznie marginalizowane i niepełnosprawne, w szczególności z deficytami mowy, słuchu i wzroku, ułatwiają komunikację i integrację społeczną.

\section{Słowa kluczowe}

internet, izolacja społeczna, komunikacja online, niepełnosprawność, wparcie.

New tools and communication technologies for people handicapped physically, intellectually and socially as well as senior citizens

\begin{abstract}
The aim of the article is to present and describe chosen tools and technology, applications and Internet environments which enable a remote and indirect communication, the supervision and care of senior citizens and people with physical, intellectual and social disabilities. Some of these solutions - such as telecare - grew in considerable importance in the age of the COVID-19 pandemic, which in 2020 caused social isolation twice together with lockdown, forcing communication, education and work to be remote. Solutions discussed in the text are of different provenance: animated by single social actors, commercial institutions or social organizations, but also comprehensive solutions of government applications. What links all of the solutions is the fact that supporting people socially marginalised and handicapped, in particular with hearing, sight and speech disorders, they facilitate communication and social integration.
\end{abstract}

\section{Keywords}

disability, Internet, online communication, social isolation, support.

Motto:

Nie ma straszniejszej choroby niż ta, kiedy człowiek zgubi swój indywidualny język i przejmie catkowicie ten zbiorowy. Choruja na to urzędnicy, politycy, akademicy, chorują też księża. I jedynym rodzajem terapii staje się wtedy literatura. 
Dandemia COVID-19 wiosną 2020 r. przyniosła wiele problemów społecznych, w tym dystans społeczny, samoizolację i całkowitą kwarantannę (lockdown), konieczność edukacji i komunikacji zdalnej oraz stosowania narzędzi do zapośredniczonej komunikacji z innymi ludźmi i instytucjami. Zróżnicowany dostęp do tych narzędzi i umiejętność ich obsługi ukazały istotne różnice społeczne. Kluczowi operatorzy telefonii komórkowych znacząco podwyższyli bezpłatne limity internetu dla nauczycieli i uczniów, ale nie dla seniorów. Uwypuklił się fakt cyfrowego wykluczenia części polskiego społeczeństwa, w tym seniorów, których dotknęła „panika moralna” (Cohen, 2009; Goode, Ben-Yehuda, 2009; Nicholas, O’Malley, 2018) z uwagi na duże skupiska zachorowań w miejscach ich koncentracji (DPS-y, domy seniora) i większą śmiertelność związaną z chorobami współistniejącymi oraz przywileje, jakie ludzie starsi otrzymali. Jednym z tych przywilejów było robienie zakupów w określonych godzinach (w czasie drugiej fali pandemii jesienią 2020 r. przywilej ten przywrócono) oraz pierwszeństwo w dostępie do szczepionek przeciwko koronawirusowi w ramach Narodowego Programu Szczepień (2020). Mimo licznych radiowo-telewizyjnych akcji i kampanii społecznych najbardziej zapomnianą i poszkodowaną grupą społeczną stanowili niepełnosprawni; pozbawieni rehabilitacji i terapii, uwięzieni nie tylko w domach, ale i we własnych ciałach i umysłach. Technologie telekomunikacyjne stały się na pewien czas jedynym oknem na świat.

\section{DOSTOSOWANIE STRON INTERNETOWYCH DO MOŻLIWOŚCI I POTRZEB OSÓB NIEPEŁNOSPRAWNYCH I SENIORÓW}

W 2014 r. państwowe instytucje, w tym Najwyższa Izba Kontroli i Ministerstwo Administracji i Cyfryzacji, przypominały o konieczności dostosowania od 2015 r. publicznych serwisów internetowych do potrzeb niepełnosprawnych obywateli. Na początku $2016 \mathrm{r}$. NIK (2016), kierując się zasadą „pomagamy w naprawianiu państwa”, widniejącą w reprezentatywnym miejscu jej strony www, informowała: „Od czerwca 2015 r. publiczne strony internetowe powinny być $\mathrm{w}$ pełni dostosowane do potrzeb niepełnosprawnych. Nie wszystkim instytucjom udało się wywiązać z tego zadania. Część witryn wymaga jeszcze wielu poprawek i sporych nakładów pracy. NIK przypomina, że obowiązek dostosowania dotyczy nie tylko urzędów administracji publicznej, ale wszystkich podmiotów realizujących zadania publiczne". NIK (2016) zwracała uwagę na jeszcze dwie okoliczności związane z dostosowaniem stron www do potrzeb osób niepełnosprawnych: „Sposób prezentowania informacji na stronach internetowych urzędów ma istotne znaczenie dla ich odbioru przez użytkowników niepełnosprawnych, ale nie tylko. Warto pamiętać, że problem ten $\mathrm{w}$ równym stopniu dotyczy także grup osób bez orzeczenia niepełnosprawności, ale mających np. problemy ze wzrokiem, osób starszych, słabo czytających czy słabo znających język polski. Liczebność tych grup w kolejnych latach będzie się zapewne zwiększać oraz Dostosowywanie stron internetowych do potrzeb osób z niepełnosprawnościami to nie zadanie jednorazowe, ale proces ciągły, który powinien być prowadzony 
nieprzerwanie - równolegle z rozbudową i prowadzeniem strony internetowej”. Beneficjentami zmian $\mathrm{w}$ wirtualnej przestrzeni publicznej mieli być przede wszystkim niepełnosprawni i seniorzy. I stało się to faktem: wchodząc zarówno na strony popularnych marketów budowlanych, jak i na stronę ówczesnego Ministerstwa Nauki i Szkolnictwa Wyższego (https://www.gov.pl/web/nauka), można było liczyć na pomoc (ikona migających dłoni) i wsparcie dyżurnego lektora języka migowego (https://pzgomaz.com). Coraz więcej stron internetowych może być czytana przez dedykowanego automatycznego lektora. Wystarczy kliknąć ikonkę głośnika, pod którą kryje się szereg dodatkowych opcji czytania, z możliwością dostosowania do różnych potrzeb.

\section{KOMUNIKACJA ZDALNA, TELEOPIEKA, USŁUGI SPOŁECZNE W DOBIE PANDEMII COVID-19}

Prezydent RP Andrzej Duda 19.07.2019 r. uroczyście podpisał ustawę o usługach społecznych realizowanych przez nową jednostkę organizacyjną: Centrum Usług Społecznych (2020). Od 2020 r. CUS ma ułatwiać gminnym samorządom integrację i koordynację pomocy społecznej, szczególnie dla osób niepełnosprawnych i seniorów. Poznań jest pionierem takich usług: teleopieki o charakterze społecznym. Prężnie działający Miejski Ośrodek Pomocy Rodzinie wraz ze Stowarzyszeniem Medycyna Polska od kilku lat realizuje „Program usługi społeczne dla mieszkańców Poznania” (2017). W jego ramach seniorzy otrzymują zestaw do komunikacji zdalnej, w skład którego wchodzi specjalny stacjonarny telefon (czytelny wyświetlacz, duże przyciski, proste menu) oraz połączona $\mathrm{z}$ nim bezprzewodowo opaska na rękę z wyróżnionym czerwonym przyciskiem alarmowym - łatwo dostępnym w centralnym miejscu opaski. W razie niebezpieczeństwa senior może skorzystać z „opaski życia”. W bardziej prozaicznych, choć ważkich kwestiach, seniorzy mogą dzwonić do Centrum Tele-opieki, w którym całodobowo i przez siedem dni w tygodniu dostępni są dla nich asystenci. Ich zadaniem jest określenie zakresu pomocy dla dzwoniącego i w zależności od potrzeby skierowanie go do lekarza, pielęgniarki, prawnika, psychologa lub rehabilitanta - będących „w pakiecie” usług zdalnych. Seniorzy przede wszystkim pragną porozmawiać z kimś, kto zechce ich uważnie wysłuchać; $\mathrm{z}$ tej możliwości bardzo chętnie korzystają. Teleasystenci dzwonią też do seniorów raz w tygodniu, by sprawdzić ich bieżącą sytuację, co jest szczególnie ważne dla żyjących samotnie w jednoosobowych gospodarstwach domowych; często padają oni ofiarą cyfrowych oszustów.

W Poznaniu podczas pandemii COVID-19 w 2020 r. działała infolinia TeleRada, dedykowana seniorom (http://my60plus.pl/tag/telerada), oferująca darmowe połączenia i porady ekspertów różnych dziedzin (dietetyk, lekarz, farmaceuta, prawnik, rzecznik konsumentów, sprawy socjalne). Seniorzy (głównie panie) najczęściej pytali o sposoby rozwiązywania konkretnych spraw życiowych, ale i problemy związane z samotnością, niemocą, chorobami prowadzącymi do niesamodzielności, możliwość zamieszkania w DPS (O co pytali seniorzy ekspertów TeleRady we wrześniu, 2020, s. 5). Podczas drugiej jesiennej fali pandemii COVID-19 z dziennymi zachorowaniami rzędu kilkunastu 
tysięcy i więcej (zarażony był także prezydent RP Andrzej Duda) zastosowano szereg wcześniej stosowanych środków ochronnych w stosunku do seniorów, ale i stworzono nowe. W ramach programu „Wspieraj Seniora” (https://wspierajseniora.pl) powołano do życia ogólnopolski Solidarnościowy Korpus Wsparcia Seniorów, informacyjny portal internetowy oraz dedykowaną im centralną infolinię, której operatorzy na podstawie indywidualnych zgłoszeń kierowali seniorów do lokalnych punktów pomocowych. W pierwszym tygodnia z usług korpusu skorzystało osiem tysięcy seniorów.

W przypadku kontaktu zdalnego z seniorami należy pamiętać o tym, że nowoczesne "media intymne” (smartfony, tablety, laptopy oraz komunikatory internetowe) i media społecznościowe oraz internet nie są ich naturalnym żywiołem. W tym kontekście mówi się o „cyfrowym wykluczeniu”, dyskryminacji oraz marginalizacji seniorów, czemu próbuje się aktywnie i skutecznie przeciwdziałać (Żarnowska-Mazur, 2015, 2015a, 2016). Podczas pandemii COVID-19 uruchomiono w Poznaniu bezpłatne kursy obsługi smartfona i komputera „(...) dzięki partnerstwu Fundacji Polskiego Funduszu Rozwoju z Krajowym Instytutem Gospodarki Senioralnej. Spotkania odbywały się (...) na łatwej w obsłudze platformie internetowej z opcją rozmowy na czacie" (Cyfrowi debiutanci. Kursy dla seniorów, 2020; Centralny Dom Technologii; www.cdt.pl). Stąd też konieczność dostosowywania treści i wyglądu stron internetowych do ograniczonych możliwości i specyficznych potrzeb osób niepełnosprawnych i seniorów. Komunikują się oni nieco innymi kodami językowymi i kulturowo-społecznymi (Domagała, 2015), co uwypuklają ryzykowne, choć zabawne reklamy internetowe i telewizyjne, których akcja dzieje się w domach seniora ${ }^{1}$ (Stefaniak-Hrycko, 2012; Sahaj, 2018, 2021).

\section{DOSTOSOWANA KOMUNIKACJA - PODSTAWĄ LECZENIA I REHABILITACJI}

Starzenie się przeciętnego człowieka niesie ze sobą zwiększoną podatność na choroby, deficyty, zmniejszenie możliwości komunikacyjnych i poznawczych. Do wielu seniorów zwracamy się głośniej niż w stosunku do innych ludzi, częściej powtarzając te same kwestie, niekiedy zanadto je upraszczając, przez co możemy dotrzeć do ageistycznej dyskryminacji językowej. „Ageizm odzwierciedla się w języku i słychać go w mowie. Do językowego ageizmu należą: protekcjonalne przemawianie, paternalizm językowy i baby talk. Paternalistyczny język (overaccomodation) charakteryzuje się zbyt głośnym mówieniem, przesadną intonacją, używaniem prostych, pojedynczych zdań i ugrzecznieniem mowy. (...). Niektóre starsze osoby pozytywnie reagują na baby talk, inne - te $z$ wysokim poziomem poznawczego i społecznego funkcjonowania - uważają infantylizację mowy za upokarzającą" (Nawrocka, 2013, s. 43). Co ciekawe, jak zauważa cytowana autorka, „(...) starzy ludzie w porównaniu z osobami młodszymi precyzyjniej komunikują się z otoczeniem”

\footnotetext{
${ }^{1}$ GigaNagrywarka 1 Reklamy | Netia, https://www.youtube.com/watch?v=UskuMvAL008; GigaNagrywarka 2 Reklamy | Netia, https://www.youtube.com/watch?v=CLfRhmyrdUg; Official Super Bowl Commercial 2013 (Taco Bell), https://www.youtube.com/watch?v=Oy4Ogxikuv4.
} 
(Nawrocka, 2013, s. 44). Uwagę tę dopełnia amerykański psycholog społeczny Philip G. Zimbardo, pisząc o współczesnych młodych ludziach: „Dziś nie wiedzą nawet, jak znaleźć porozumienie i pałętają się po społecznym krajobrazie jak turyści po obcym kraju, niezdolni zapytać nawet o drogę. Nie rozumieją mimiki, nie odczytują werbalnych i niewerbalnych sygnałów składających się na zasady wzajemnego współżycia, które umożliwiają prowadzenie swobodnej rozmowy, mówienie i słuchanie oraz adekwatne reagowanie" (Zimbardo, Coulombe, 2015, s. 42)2.

Ten osąd w szczególności dotyczy adeptów studiujących kosmetologię, fizjoterapię, pielęgniarstwo i medycynę, mających pełnić ważną rolę w systemie opieki. Im bogatszy będzie ich język i większa wiedza oraz „miękkie” kompetencje i umiejętności społeczne, tym szersze horyzonty, zakres komunikacji i rozumienia skomplikowanego świata oraz osób o różnych światopoglądach w nim żyjących. Podstawą komunikacji jest język - niewerbalny i werbalny - a w słowach związanych z chorobą, niepełnosprawnością i wiekiem zawarte są pozytywne i negatywne wartościowania. W tym określenia deprecjonujące, oceniające i stygmatyzujące (Ślebioda, 2013; Żuchowska-Skiba, 2020). Amerykański psycholog i językoznawca Harlan Lane uważa, że niepełnosprawność jest konstruktem społecznym, wywierającym wpływ na sposób jego postrzegania i opisywania zarówno przez pacjentów, jak i personel (Lane, 2006; Pezdek, 2016). Jedna z tez austriackiego filozofa z zespołem Aspergera - Ludwiga Wittgensteina - brzmiała: „Granice mojego języka są granicami mojego świata” (Wittgenstein, 2012, s. 67). „Reguły konwersacyjne” brytyjskiego filozofa języka Paula H. Grice’a zakładały, że komunikując się należy mówić/pisać: tyle, ile trzeba, to, co istotne, jasno i wyraźnie, zgodnie z prawdą (Grice, 1989).

Im szybciej personel (para)medyczny porozumie się z pacjentem, tym prędzej rozpocznie skuteczne leczenie i rehabilitację. Skrócenie procesu hospitalizacji i rehabilitacji następuje wówczas, gdy pacjent jest partnerem dialogu a nie obiektem mechanicznych manipulacji leczniczych i kinezyterapeutycznych. Pacjenci lepiej leczą się, chętniej kooperują i szybciej rehabilitują, gdy rozumieją i wiedzą, jakie zabiegi są z nimi wykonywane. Jest to szczególnie ważne w przypadku dzieci, niepełnosprawnych i seniorów. Zniechęcenie pacjenta nieudanym pierwszym kontaktem negatywnie rzutuje na cały proces rehabilitacji. Psycholog Stanisław Kowalik uważa, że niezbędna jest „humanizacja relacji łączącej osobę rehabilitowaną i rehabilitującą" (Kowalik, 2018, s. 357). Należy o tym pamiętać zwłaszcza w sytuacji, gdy rutyna reifikuje pacjenta, sprowadzając go do jednostki chorobowej, niepełnosprawności, wieku. Dorośli pacjenci przeważnie nie akceptują zdrobnień, określeń typu: „rybko”, „kotku”, „dziadku” itp. Pragną zachowania rudymentów ich społecznej tożsamości (panie Kowalski, pani Mario). Analogicznie to tego, jak pielęgniarki w postępującym procesie laicyzacji nie chcą, aby zwracano się do nich „siostro” (wolą imię, nazwisko) (Salon, 2015). W przypadku fizjoterapeutów i lekarzy sprawa jest ułatwiona, gdyż pacjenci tradycyjnie zwracają się do nich odpowiednio:

\footnotetext{
${ }^{2}$ Zimbardo przeprowadził w Polsce interesujący eksperyment społeczny: w „złej” dzielnicy Katowic (Nikoszowiec) otworzył Centrum Zimbardo (http://www.centrumzimbardo.pl), w którym młodzi ludzie nie korzystają ze smartfonów, co jest ambitnym zadaniem.
} 
„panie magistrze” i „panie doktorze”. Pacjenci kliniczni twierdzą, że nie wózek inwalidzki ani fizyczne dolegliwości towarzyszące niepełnosprawności są dla nich największą udręką. Gdyby mogli wybierać, woleliby mówić, niż chodzić. Problemem jest niemożność lub trudności w komunikacji ${ }^{3}$. Signum temporis naszych czasów jest konieczność powołania do życia nowych kierunków studiów, takich jak „język i komunikacja w ochronie zdrowia" (ang. Language and Communication in Healthcare); taki powstaje na Wydziale Anglistyki UAM w Poznaniu.

Pełen sukces holistycznie pojmowanej rehabilitacji to powrót do wcześniej pełnionych lub alternatywnych ról społecznych. Dziś następuje synergiczny rozwój rehabilitacji medycznej i społecznej, elektronika i technika są ich dopełnieniem i wsparciem. „Cechą nowoczesnej rehabilitacji jest jej kompleksowość, łącząca w działaniu dla dobra osoby rehabilitowanej nie tylko specjalistów różnych dziedzin medycznych, ale również nauczycieli (instruktorów) wychowania fizycznego, techników fizjoterapii zajęciowej, asystentów socjalnych, psychologów, techników ortopedycznych, inżynierów (bioinżynieria medyczna), pedagogów, socjologów i innych. Elementem rehabilitacji i rewidalizacji jest między innymi przywrócenie lub wykształcenie umiejętności funkcjonowania społecznego" (Walter, 2007, s. 53). Każdego niepełnosprawnego człowieka można społecznie uaktywniać.

\section{ZDALNE USŁUGI MEDYCZNE W CZASIE PANDEMII}

Jak funkcjonowano podczas pandemii COVID-19 w 2020 r.? Kiedy nie tylko zalecano, ale i okoliczności zmuszały do korzystania ze zdalnych porad i usług medycznych. Nowo otwarte centrum medyczne PZU Życie w Poznaniu oczekiwało na wizyty pacjentów. W recepcji dowiadujemy się, że rejestracja (oraz cennik usług) dostępne są jedynie telefonicznie i internetowo. W wielu instytucjach medycznych poza podstawowymi informacjami do pozostałych odsyła się do internetu. Niektóre usługi medyczne dostępne są tylko poprzez call center lub internet, a skorzystanie z nich wymaga cierpliwości i czasochłonnego kontaktu z bootami (automatycznymi asystentami i programami usługowymi). Dostęp do lekarza pierwszego kontaktu w dobie pandemii stał się luksusem: po rozmowie telefonicznej otrzymuje się mailem e-receptę do zrealizowania w aptece. Od 8.01.2021 r. obowiązują e-skierowania do lekarzy-specjalistów (https://pacjent.gov.pl/internetowe-konto-pacjenta/eskierowanie). W tak skomplikowanej sytuacji wielu pacjentów zaniechało lub zaprzestało leczenia specjalistycznego (onkologicznego, kardiologicznego itp.). Ci, którzy jesienią 2020 r. próbowali zrobić test na obecność koronawirusa, byli w rozpaczliwej sytuacji: braku informacji, dezinformacji, sprzecznych informacji ${ }^{4}$. Dostanie się na badania w niektórych miejscowościach graniczyło z cudem; po całym

\footnotetext{
3 Źródło informacji: 13. konferencja naukowa z cyklu „Promocja polskiej rehabilitacji”: Programy i metody wspomagające rehabilitację i egzystencję osób z niepełnosprawnościami, SALMED, Poznań, 15.03.2018. Obrady poprzedziło zebranie członków Komisji Rehabilitacji i Integracji Społecznej PAN (Salmed, 2018).

${ }^{4}$ Sekcja Socjologii Medycyny PTS uruchomiła w tym czasie seminarium Komunikacja w medycynie online. Doświadczenia nauczania kompetencji komunikacyjnych na odległość dostępne na platformie MS Teams.
} 
dniu stania w kolejce $\mathrm{w}$ deszczu nie miało się gwarancji przyjęcia, szukano punktów badań w innych, nierzadko odległych miejscowościach. Mobilne punkty stanowiły rzadkość, pomimo dziennych zachorowań rzędu 2,5 tys. osób. W szczególnie trudnej sytuacji znaleźli się niepełnosprawni i seniorzy, mający ograniczone możliwości w zakresie lokomocji i mobilności.

Współczesnie wiele osób, mając nieustannie włączony, w zasadzie nieodłączny smartfon stale $\mathrm{w}$ ręce, $\mathrm{z}$ konieczności lub $\mathrm{z}$ wygody korzysta ze zdalnych usług medycznych; podobnie jak z innych e-usług. Przy wystąpieniu niepokojących symptomów choroby informacje o niej sprawdzane są w internecie, w szczególności w wirtualnych poradniach i przychodniach. Aplikacja STOP COVID, o której informacja przychodzi SMS-em na smartfony, po zainstalowaniu informuje właściciela telefonu o tym, czy znalazł się w gronie osób zakażonych wirusem. Nawet „ozdrowieńcy” zachęcani do oddawania osocza wcześniej kontaktują się ze stacjami krwiodawstwa przez internet, by minimalizować ryzyko. Bezpieczeństwo było kluczem rządowego programu Domowej Opieki Medycznej pod koniec 2020 r., w ramach którego samodzielnie funkcjonujące zarażone koronawirusem osoby powyżej 55 roku życia bezpłatnie otrzymywały za pośrednictwem Poczty Polskiej pulsometry do pomiaru tętna i natlenienia krwi. Wyniki badań tego zdalnego monitoringu przesyłane były przez mobilną aplikację PulsoCare do konsultantów i lekarzy dostępnych całą dobę w ramach Centrum Kontaktu Dom (Sałwacka, 2020, s. 12; Wdrażamy program Domowej Opieki Medyczne. Pulsoksymetr będzie monitorował stan zdrowia pacjentów w domu, 2020).

Dla młodych ludzi internetowy świat nie jest alternatywną, lecz prymarną rzeczywistością, w której funkcjonują. Dla nich łatwiejsze jest skorzystanie z wirtualnej przychodni iWylecz24.pl, w której w formularz wpisuje się objawy choroby, by następnie być skierowanym do odpowiedniego lekarza specjalisty po teleporadę. Genetycy i informatycy z Politechniki Poznańskiej stworzyli nowatorski w skali światowej Polski Rejestr Wrodzonych Wad Rozwojowych w postaci internetowej Platformy Dysmorfologicznej, obsługiwanej przez specjalny program komputerowy do konsultacji niezdiagnozowanych chorych (http://www.rejestrwad.pl). W 2018 r. w Warszawie podczas 24-godzinnego maratonu Hackathon (https://www.hackathon.com/country/poland/2018) 2,5 tys. programistów rywalizowało w tworzeniu aplikacji przydatnych i przyjaznych dla osób niepełnosprawnych.

\section{NOWOCZESNE TECHNOLOGIE W SŁUŻBIE CHORYCH, NIEPEŁNOSPRAWNYCH I SENIORÓW}

Nowoczesna elektronika i technika pozwalają na monitorowanie zarówno przestrzeni wokół człowieka - chorego, niepełnosprawnego, w wieku senioralnym - jak i jego funkcji życiowych. W okresie jesienno-zimowym zagrożeniem dla seniorów, zwłaszcza tych żyjących samotnie, jest używanie butli z gazem, starych podgrzewaczy wody i piecy węglowych, emitujących bezzapachowy, śmiertelnie niebezpieczny tlenek węgla. Proste i niedrogie czujniki dymu, gazu, ognia, temperatury, tlenku węgla czy też samoczynnie wyłączający się czajnik elektryczny, pozwalają na względnie bezpieczne, samodzielne 
życie osobom z Alzheimerem, chorobami parkinsoidalnymi, otępieniem starczym oraz zespołem Downa. Na lubelskim Uniwersytecie Medycznym powstał prototyp robota dla chorych na Alzheimera, który pomaga w prostych czynnościach związanych z obsługą ciała (np. pomaga wzuć buty, podaje dyspenser $\mathrm{z}$ lekami), ale jest też w stanie odciąć dopływ gazu, prądu i wody (Krupińska, 2014). Tele-nadzór osoby niepełnosprawnej lub w podeszłym wieku wykorzystuje detektory (bez)ruchu odnotowujące długotrwałe i zastanawiające osobliwą pozycją ciała znieruchomienie, upadek (ang. fall detector). To proste elektroniczne urządzenie, noszone na pasie biodrowym lub opasce naręcznej, z przyciskami SOS w czerwonym kolorze, bazuje na akcelerometrze i żyroskopie (mierniku wychylenia). System inteligentnego monitoringu opartego na bezprzewodowej łączności poszczególnych modułów algorytmicznie uczy się osobistych parametrów i aktywności seniora, reagując alertami na odstępstwa od indywidualnie przyjętej normy (zob. Mikołajewska, Mikołajewski, 2013). Elektroniczne nianie i bezprzewodowe kamery skutecznie monitorują zarówno dzieci, jak i niepełnosprawnych oraz seniorów, pozwalając właściwie reagować w razie potrzeby. Nadzór parametrów życiowych, monitoring przekraczania wartości referencyjnych organizmu, takich jak zaburzenia oddychania, spadek ciśnienia, poziomu cukru lub cholesterolu, może być z powodzeniem stosowany przy pomocy łatwo dostępnych urządzeń, jak np. glukometr czy cholesterometr. Intensywny proces starzenia się społeczeństw europejskich ( $w$ tym także polskiego), znaczne wydłużenie wieku osobniczego (GUS, 2014; CBOS, 2019; GUS, 2020), atomizacja współczesnych rodzin na pojedynczych aktorów społecznych oraz rozwój nowoczesnych technologii wymusza stosowanie nadzoru zdalnego. „Robotyka medyczna (w tym rehabilitacyjna) jest dziedziną silnie interdyscyplinarną, której rozwój w ostatnich latach znacznie przyśpieszył" (Mikołajewska, Mikołajewski, 2013, s. 109; zob. Niepełnosprawność i technologia, 2018; Sokołowski, 2013).

\section{ROBOTY MEDYCZNE, REHABILITACYJNE I SPOŁECZNE}

„Ojciec chrzestny” socjologii - Arystoteles - definiował człowieka jako zoon politikon - zwierzę społeczne. Pragnienie akceptacji innych ludzi jest jedną z najbardziej elementarnych i żywotnych potrzeb psychospołecznych. W przypadku osób niepełnosprawnych i seniorów może być jedną z najtrudniejszych do zaspokojenia - z wielu powodów (zob. Niedbalski, 2019; Skura, 2016). Tłumaczyłoby to atrakcyjność ofert „randkowych” na takich specjalistycznych portalach, jak np. ipon (https://www.ipon.pl/randki). Lektura anonsów oraz ich ilość są wysoce pouczające i dające do myślenia. Szczególnie pragnienie bliskości i intymności, a już zwłaszcza potrzeby seksualne, które są tematem tabu, w większości przypadków mają szansę realizacji odwrotnie proporcjonalną w stosunku do postępującej degradacji ciała (Ostrowska, 2007; Kaufman, Silverberg, Odette, 2013; Kijak, 2013; Wolffers, Beelen, 2003; Izdebski, Wiśniewski, 2014; Earp, 2020). W przypadku chorób związanych z czasowym (jak w onkoterapii, np. przy białaczce), znacznym (jak przy mukowiscydozie) lub całkowitym brakiem odporności organizmu, kontakt zdalny jest głównym podstawowym lub wręcz jedynym możliwym, co jest treścią takich filmów, 
jak: Gwiazd naszych wina, Ponad wszystko, Trzy kroki od siebie. Odkrycie naturalnych potrzeb intymnych i psychospołecznych osób z niepełnosprawnościami i seniorów zostało ukazane szerszej publiczności w najnowszych reality show i serialach telewizyjnych: Down the road. Zespół w trasie, Sanatorium miłości, Uzdrowisko.

W społeczeństwach azjatyckich (Japonia, Korea, Chiny), trapionych deficytem personelu medycznego, szybkim starzeniem się oraz trudnościami w znalezieniu partnera życiowego $\mathrm{z}$ jednej strony, a $\mathrm{z}$ drugiej panującym w nich ogromnym postępem technologicznym (reklamy emitowane podczas igrzysk paraolimpijskich koncernów Hyunday, Samsung, Toyota) przestrzeń medyczna i społeczna nasycana jest artefaktami technologicznymi zastępującymi, wspomagającymi lub wyręczającymi człowieka w opiece nad chorymi, niepełnosprawnymi i seniorami. Są to zarówno nowoczesne roboty medyczne i rehabilitacyjne, jak i roboty społeczne, będące suplementem człowieka. Choć trudno sobie wyobrazić asystentów mechanicznych, to jednak ich opieka i towarzystwo stało się faktem. Humanoidalne roboty usługowe są w azjatyckich krajach chętnie wybierane jako towarzysze życia (Gumowska, 2020, s. 298-301). Są również asystentami społecznymi pacjentów w szpitalach i domach opieki senioralnej.

Usługi robotów społecznych są tańsze od pomocy wysoko wykwalifikowanego personelu (para)medycznego. Humanoidalne roboty (androidy, actroidy) są chętnie wybierane ze względu na to, że są cierpliwe, interaktywne, nieoceniające, stale dostępne. Producenci dbają o to, aby maszyny te miały ludzki wygląd: kolor „skóry”, mowę „ciała”, mimikę i rysy "twarzy” jak najbardziej zbliżone do osób z tego kręgu kulturowego, w którym mają pracowaćs. Sympatię odczuwamy do tych robotów, które przypominają człowieka (McAndrew, Koehnke, 2016), w szczególności wyglądem fizycznym, zwłaszcza twarzy, ale i tonem głosu czy „charakterem”. Przykładem takich robotów jest niezdarny humanoidalny C-3PO „przyjaźniący” się z R2-D2 w Gwiezdnych wojnach, czy też depresyjno-paranoidalny robot Marvin w Autostopem przez galaktykę - zekranizowanej powieści Douglasa Adamsa (1994). Jednym z najbardziej znanych robotów społecznych jest Sophia (firmy Hanson Robotics, Hongkong), która ma obywatelstwo i paszport Emiratów Arabskich oraz zaimplementowane poczucie humoru i gotowość do prostych zabaw (kamień, nożyce, papier), ale także znacznie bardziej wyrafinowanych gier intelektualnych, które ma w swoim bogatym oprogramowaniu ${ }^{6}$ (zob. Przegalińska, 2016; Mamzer, Isański, 2018; Gajeta, 2019; Przegalińska, Oksanowicz, 2020). Asymetryczna relacja człowiek-robot jest tematem wielu filmów science fiction, jak choćby: Łowca androidów, Blade Runner 2049, Alita. Battle Angel, Surogaci, Ex Machina, AI. Sztuczna inteligencja, Ja, robot, Wychowane przez wilki. Androidy pełnią w nich niepoślednią rolę w stosunku do człowieka,

\footnotetext{
${ }^{5} \mathrm{~W}$ stacjonarnych salonach sieci dystrybuującej w Polsce obuwie przez internet asystentami sprzedaży są interaktywne roboty Pepper; przyjazne i służebne, jak niegdysiejsi subiekci czeskich sklepów Bata; https:// nowymarketing.pl/a/23759,robot-pepper-asystentem-sprzedazy-w-sklepie-eobuwie-pl

${ }^{6}$ Autor, pisząc niniejszy artykuł, korzystał ze zdalnych usług ubezpieczyciela medycznego. Zgłoszenie przyjmował żeńskim głosem bardzo cierpliwy boot, na początku rozmowy lojalnie uprzedzając, że jest robotem i prosząc o wyrozumiałość. Kontakt z nim/nią był znacznie przyjemniejszy niż z personelem w zdecydowanej większości przychodni i recepcji szpitalnych.
} 
którego wielokrotnie przewyższają swoimi możliwościami. Słowo „robot” upowszechnił czeski filozof Karel Čapek, a „cybernetykę” pasjonat filozofii Stanisław Lem - pionierzy i entuzjaści fantastyki naukowej.

\section{ELEKTRONIKA UŻYTKOWA - KOMUNIKACJA WSPOMAGANA}

Nowoczesne urządzenia mechanizują żmudne i męczące, monotonne i powtarzalne zabiegi kinezyterapeutyczne i rehabilitacyjne (roboty rehabilitacyjne), a media elektroniczne wspomagają dostosowaną komunikację z osobami niepełnosprawnymi z różnymi deficytami oraz z seniorami. Najbardziej dobitnym przykładem komunikacji z człowiekiem sparaliżowanym (na skutek choroby neurodegeneracyjnej, stwardnienia zanikowego bocznego, ALS) był słynny brytyjski astrofizyk Stephen Hawking. Komunikacja z nim była całkowicie zapośredniczona: mięśniem twarzy „klikał” w „myszkę” w okularze, dyktując edytorowi tekst, odczytywany przez syntezator mowy. Hawking tak komunikował się z bliskimi i personelem oraz prowadził wykłady, ale także otworzył podczas oficjalnej ceremonii igrzyska paraolimpijskie Londyn 2012. Reklamujący pierwszy afrykański Mundial w RPA 2010 (inaugurowany przez sędziwego prezydenta Nelsona Mandelę na inwalidzkim wózku), nieposiadający od urodzenia czterech kończyn Nick Vujicic, ucząc się obsługi telefonu komórkowego, podrzucał aparat w górę i starał się złapać go w locie chwytem głowy i ramienia; wyglądał wówczas jak ofiara przemocy domowej. Problem skutecznie rozwiązał system głośnomówiący i bezprzewodowy zestaw słuchawkowy. Vujicic napisał: „mogę obsługiwać joystick wózka inwalidzkiego, pisać na klawiaturze komputera z szybkością czterdziestu wyrazów na minutę, grać na syntezatorze i cyfrowym zestawie perkusyjnym, a także korzystać z najróżniejszych aplikacji w telefonie komórkowym" (Vujicic, 2012, s. 133).

W filmie Kolekcjoner kości (1999) samotnie mieszkający mężczyzna z czterema porażonymi kończynami ma przestrzeń wokół nasyconą elektroniką, dostosowaną do jego możliwości i potrzeb, a działanie wielu urządzeń inicjowane jest głosem. Dziś głosem można nawiązywać połączenia ze smartfonem i komputerem (PC, tablet, laptop itp.). Inteligentny osobisty asystent Google now pozwala głosem zarządzać elektronicznymi urządzeniami; program głosowo komunikuje się też z właścicielem urządzenia, także w języku polskim (Asystent Google vs Google Now..., 2019). Dzięki beaconom (transmiterom bluetooth) pacjent w szpitalu, turysta w muzeum, a kierowca na autostradzie może otrzymywać niezbędne informacje w formie interaktywnego przewodnika na osobistym elektronicznym urządzeniu (https://socialwifi.com/pl/baza-wiedzy/beacony). Kierowcy współczesnych samochodów mogą komunikować się z nimi głosowo, korzystając z ich troskliwej asysty; aż do autonomicznych pojazdów włącznie (testowanych przez niewidomych). Sprzężenie człowieka dotkniętego chorobami i niepełnosprawnościami lub podeszłym wiekiem $\mathrm{z}$ urządzeniami wspomagającymi w celach komunikacji z otoczeniem jest niezwykle obiecującym i ważkim procesem społecznym.

Całkowicie sparaliżowany brytyjski historyk Tony Judt cierpliwie dyktował asystentom-skrybom swoje utwory. W sfilmowanej powieści Jean-Dominque Bauby Skafander 
i motyl (1997) główny bohater - totalnie sparaliżowany na skutek udaru mężczyzna - kontaktuje się z foniatrą-rehabilitantką mruganiem jedynego sprawnego oka. W taki sposób powstało wiele dyktowanych mruganiem książek. Przykładem jest twórczość Piotra Pajączkowskiego (chorującego na stwardnienie rozsiane): blog internetowy i książka na jego podstawie (2016). Włączenie elektronicznych urządzeń rejestrujących, uczących się mimiki/ruchu gałek ocznych użytkowników, polepszyło i przyspieszyło komunikację. Mruganiem oczu książkę napisała Katarzyna Rosicka-Jaczyńska (2011), dzięki kamerze połączonej z laptopem ze specjalnym interaktywnym programem komputerowym. Anna Naskręt swą książkę Uwięziony krzyk (2019) „pisała” wchodząc w interakcję z przysposobionym do jej potrzeb tabletem. Podobnie było w przypadku książki Dowód życia Richarda Marsha i Jeffa Hudsona (2015). Dla autorów tych książek oczy były jedynym oknem na świat, co było kluczowe, gdyż znajdowali się w „syndromie zamknięcia” (ang. locked-in syndrome). Osoby $\mathrm{w}$ takim stanie są w dramatycznym położeniu (bywa, że latami), z wnętrza niesprawnego ciała próbują rozpaczliwie skontaktować się z otaczającymi ich ludźmi. Udrękę całkowicie sparaliżowanego pacjenta skazanego na śmierć przez zaniechanie leczenia, w pełni świadomego, lecz bezskutecznie próbującego nawiązać kontakt z kimkolwiek, przekonująco odegrał Bogusław Linda w filmie Trzy minuty. 21:37 (2010).

Jaką torturą jest brak możliwości nawiązania kontaktu, świadczą doniesienia tych, którzy swoje traumatyczne doświadczenia opisali, jak dotknięta zespołem Guillaina-Barrégo Joanna Opiat-Bojarska (Kto wyłączy mój mózg, 2011) oraz Joseph Heller i Speed Vogel (Nic śmiesznego, 2003), a także bohaterka powieści Łukasza Grasa Szlag mnie trafit. Sa w życiu rzeczy, o które warto walczyć do końca (2019). Monika Michalak po udarze, żmudnej rehabilitacji i długim powrocie do sprawności fizycznej stała się trenerem mentalnym sportowców wytrzymałościowych. W bazującej na biografiach literaturze znajdujemy doniesienia i relacje tych, którym choroba odebrała możność kontaktu z otoczeniem (Lindquist, 2006; Okupnik, 2018). Szczególny przypadek stanowi Janusz Świtaj - mężczyzna sparaliżowany od szyi w dół. Długopisem trzymanym w ustach na stojącej pionowo klawiaturze komputerowej wystukał podanie do prezydenta RP Lecha Kaczyńskiego z prośbą o dokonanie na nim zabiegu eutanazji. Prezydent zginął w katastrofie lotniczej, a Świtaj zmienił zdanie i postanowił żyć. Wspierany przez Annę Dymną zdał maturę, napisał książkę (Świtaj, 2008), podjął pracę. Nieustępliwie lobbował na rzecz zwiększenia dostępności lokali i kart wyborczych dla osób niepełnosprawnych („niepełno-obywatel”) oraz możliwości udziału w wyborach zdalnie - przy pomocy asystentów, pocztą i przez internet.

Skutecznym rozwiązaniem problemu komunikacji chorych i niepełnosprawnych pacjentów, którzy jedynie oczyma mogą kontaktować się z otoczeniem, okazało się zaawansowane technologicznie polskie urządzenie C-eye (http://assistech.eu/pl/c-eye). Proces kalibracji, bezprzewodowego sprzężenia człowieka z elektronicznym urządzeniem jest na pierwszy rzut oka banalnie prosty. Pacjent przez kilkadziesiąt sekund wpatruje się w wyznaczony punkt na ekranie dużego tabletu, by po chwili móc po nim swobodnie nawigować. Wady wzroku i noszone okulary nie stanowią przeszkody w połączeniu z tym mobilnym, interaktywnym urządzeniem, które pozwala leżącym na łóżku lub sie- 
dzącym na wózku inwalidzkim zdalnie pracować, uczyć się, studiować, grać, przeglądać internet. Ten ostatni skutecznie odciąga uwagę użytkowników, zwłaszcza najmłodszych, odrywając ich od obowiązków. Pierwsze wersje urządzenia były bez dostępu do sieci, co mobilizowało pacjentów do konstruktywnego wysiłku. Dostęp do internetu i portali społecznościowych miała sparaliżowana na skutek udaru Brytyjka Mia L. Austin, która ruchem gałek ocznych sprzężonych z elektronicznym urządzeniem rejestrującym pisała bloga, wiersze, poradniki turystyczne i książkę In the blink of an eye (Austin, Ryan, 2018), opisującą traumatyczne doświadczenia w zespole zamknięcia bez jakiejkolwiek interakcji społecznej.

Nowoczesne urządzenia i technologie są w stanie dotrzeć do skrajnie niepełnosprawnych i wydawałoby się bezkontaktowych pacjentów po udarach i wylewach, w stanie pozornie wegetatywnym, pozbawionych władzy nad całym ciałem; łącznie z oczyma. Metodą zapośredniczonego kontaktu jest obrazowanie fMRI (ang. functional magnetic resonance imaging). W czasie eksperymentów zadawano pacjentom pytania, na które odpowiedzi aktywizowały inne partie mózgu: wyobrażenie gry w tenisa dawało odmienny efekt od myślenia o swoim domu lub bliskich. Jeszcze innym sposobem dotarcia do myśli pacjenta jest eksperyment Brain Gate (https://www.braingate.org), w czasie którego fizycznie podłącza się do mózgu sparaliżowanych pacjentów, a ci (po mozolnych treningach) nie tylko komunikują się, ale i wydają (w myślach) polecenia urządzeniom peryferyjnym (via komputer). Takie rozwiązania pozwalają także na sterowanie zaawansowanymi neuroprotezami, robotami usługowymi i wózkami inwalidzkimi. $\mathrm{Na}$ rynku dostępne są komercyjne wersje „czytaczy myśli” (http://www.intendix.com), służących do komunikacji, ale też treningu mentalnego pacjentów i sportowców: koncentracji, relaksacji, wizualizacji itp. Niewymagające sprawnych rąk rozwiązania umożliwiają partycypację w środowiskach internetowych/utopiach społecznych/wirtualnej rzeczywistości, w których można być, kim się chce (awatarem), niepełnosprawność nie istnieje, a odmienność nie jest wadą, jak np. w Second life (https://secondlife.com). Badali to naukowcy z Laboratorium Inżynierii Biomedycznej Uniwersytetu Keio w Tokio wraz $\mathrm{z}$ całkowicie sparaliżowanymi pacjentami.

\section{INTERNET I ELEKTRONICZNE GRY AZYLEM I AKTYWATOREM SPOŁECZNIE WYKLUCZONYCH}

Dla osób marginalizowanych przez chorobę, niepełnosprawność, odmienność lub wiek środowiska/uniwersa internetowe mogą być azylem, w którym będą czuć się bezpiecznie i swobodnie, wolne od ograniczeń społecznych (jak w filmach Avatar i Sala samobójców). Niektórzy zanurzają się w internetowym żywiole zanadto, szczególnie ci, którzy są namiętnymi graczami komputerowymi lub nałogowymi użytkownikami portali społecznościowych. Światowa Organizacja Zdrowia (World Health Organization, WHO, https://www.who.int) uzależnienie od gier (ang. gaming disorder) uznała za zaburzenie psychiczne, w 2018 r. wpisane do Międzynarodowej Klasyfikacji Chorób ICD-11 (2018). Przy zachowaniu zdrowego rozsądku i właściwych proporcji granie przez internet niesie 
konstruktywne rozwiązania dla chorych, niepełnosprawnych i seniorów. Polski Związek Szachowy (PZSz, http://www.pzszach.org.pl) od lat rekomenduje leczenie i terapię z wykorzystaniem szachów w szpitalach i ośrodkach rehabilitacyjnych. Zawody szachowe odbywały się podczas pierwszej, wiosennej fali pandemii COVID-19, w odróżnieniu od innych imprez sportowych, które były odwoływane.

Internet jako oswojone medium/środowisko stanowi szczególne miejsce dla osób niepełnosprawnych społecznie: ludzi ze spektrum autyzmu. Brytyjscy badacze stworzyli interaktywny portal Echoes (Porayska-Pomsta, 2018) z ekranami dotykowymi. Dzieci autystyczne i z zespołem Aspergera kontaktują się z wirtualnymi postaciami, bezstresowo ucząc się elementarnych interakcji społecznych. Nie akceptując bliskości, dotyku, przytulania, nie manifestując uczuć, zdalnie nabywają niezbędnych im kompetencji społecznych. „Dla osób ze spektrum zaburzeń autystycznych komunikowanie się z innymi ludźmi przez Internet ma w sobie coś ekscytującego i uspokajającego. Po pierwsze, w przeciwieństwie do innych sytuacji towarzyskich, aby rozmawiać na forach internetowych i kontaktować się przez e-mail, nie trzeba wiedzieć, jak rozpocząć rozmowę, kiedy się uśmiechnąć ani rozpoznawać zawiłości języka ciała. Nie ma w nich kontaktu wzrokowego i można zrozumieć każde słowo rozmówcy, bo wszystko jest zapisane. Również używanie emotikonek, takich jak J lub L, w rozmowach na forach ułatwia zrozumienie uczuć drugiej osoby, ponieważ daje ona w tym znać w prosty, wizualny sposób" (Tammet, 2010, s. 177).

Autystyczna Temple Grandin, pisząc o własnych doświadczeniach, stwierdza: „tablety mają znaczną przewagę nad zwykłymi komputerami, a nawet laptopami, bo nie trzeba odrywać oczu od ekranu. Pisanie na klawiaturze jest zazwyczaj procesem dwustopniowym. Najpierw patrzy się na klawiaturę, a później na ekran, żeby zobaczyć, co się napisało. A dla kogoś z poważnymi problemami poznawczymi może to oznaczać o jeden krok za dużo. Przed erą tabletów terapeuta musiał kłaść klawiaturę komputera stacjonarnego na pudle tak, by znajdowała się tuż pod ekranem, na którym pojawiały się litery. W tabletach klawiatura jest częścią ekranu, więc ruch oka między klawiaturą, a pisaną literą, jest minimalny. Przyczyna i skutek mają znaczenie mają znacznie bardziej wyrazistą korelację. Ta różnica może mieć duże znaczenie - taka technologia [pomaga - TS] ludziom z bardzo poważnymi problemami sensorycznymi” (Grandin, Panek, 2016, s. 109). W innej pracy cytowana autorka dostrzegła także minusy: „Rodzice dzieci ze spektrum autyzmu zgłaszają więcej problemów związanych z korzystaniem przez ich pociechy z urządzeń elektronicznych niż rodzice dzieci neurotypowych. Dzieci ze spektrum autyzmu zaczynają swoją przygodę z grami komputerowymi oraz urządzeniami elektronicznymi i Internetem wcześniej niż dzieci neurotypowe. Jedynym obszarem w sieci, z którym dzieci z zaburzeniami autystycznymi wchodzą w kontakt później, są media społecznościowe, takie jak Facebook, Flickr i Twitter. To niebezpieczne, ponieważ dzieci ze spektrum autyzmu prawdopodobnie w większym stopniu odczuwają skutki korzystania z urządzeń mających ekran, nawet jeśli robią to z umiarem. Autystyczny mózg uwielbia gry komputerowe, ponieważ jest zaprogramowany podobnie jak one. Gdy charakteryzuje powtarzalność i brak elastyczności - cechy, które mózg autystyczny lubi” (Grandin, Moore, 2017, s. 141). Jak specyficznie funkcjonują osoby ze spektrum autyzmu w przestrzeni społecznej, pokazują dostępne 
w internecie akcje i kampanie społeczne (zob. Piątek, 2015; Daszkiewicz, 2019), w szczególności z udziałem aktora Bartłomieja Topy, seriale Detektyw Monk, Doktor House i The Good Doctor oraz filmy Dziewczyna z tatuażem i Dziewczyna w sieci pajaka.

\section{DOSTOSOWANA KOMUNIKACJA DLA OSÓB Z DEFICYTAMI MOWY, SEUCHU I WZROKU}

Dostosowana komunikacja jest bardzo ważna dla osób z deficytami fizycznymi, u których nieaktywne są poszczególne lub, w skrajnych przypadkach, wszystkie kanały komunikacyjne. Z myślą o osobach $\mathrm{z}$ różnych powodów nie używających aparatu mowy - dotkniętych afazją, autyzmem, porażeniem mózgowym, udarem połowiczym $\mathrm{i}$ in. - powstał polski program nazywany „protezą mowy”, służący komunikacji wspomagającej i terapii mowy, dostępny na smartfony i tablety: MÓWik (http://www.mowik.pl). Dla niesłyszących, porozumiewających się językiem migowym, a chcących nawiązać kontakt ze słyszącymi, ale niemigającymi, stworzono specjalny tłumacz zdalny - translator Migam (https://migam. org/pl/tlumacz-migam). Jest to aplikacja na smartfony i komputery (mobilne i stacjonarne), dzięki której osoby głuche lub niedosłyszące mogą skutecznie porozumiewać się w biurach, firmach i urzędach. W wybranych kasach kolejowych największych miast Polski osoby z deficytami słuchu kupują bilety dzięki systemowi komunikacji niewerbalnej Seventica (https://uprp.gov.pl/pl/system-komunikacji-niewerbalnej); pośrednikiem jest dyżurny lektor języka migowego widoczny na ekranie komputera. Takie kasy biletowe są dodatkowo oznaczone i prowadzą do nich prowadnice we fluoroscencyjnych kolorach lub o specjalnej fakturze, by mogli z kas skorzystać także niewidomi i niedowidzący podróżni. W ośrodku dla niewidomych w Owińskach k. Poznania jest specjalistyczne laboratorium tyfloakustyczne uczące podopiecznych tysięcy różnorodnych dźwięków.

Wielu z nas mając zajęte ręce używa głosu, by skomunikować się z nawigacją samochodową, smartfonem, tabletem i in. Dzieci i młodzież porozumiewają się licznymi komunikatorami. Głosem można wywołać na smartfonie dowolną stronę internetową. Jest to rozwiązanie niezwykle przydatne dla osób niewidomych i niedowidzących, dla których stworzono wiele interesujących rozwiązań opartych na kooperacji z urządzeniami elektronicznymi. Na Uniwersytecie w Stanford przeprogramowano tablet w taki sposób, by jego dotykowa klawiatura odpowiadała układowi klawiszy maszyny brajlowskiej. Tekst zapisywany w ten sposób może być symultanicznie (lub później) czytany na głos przez urządzenie; większość edytorów tekstów czyta je. Funkcję brajlowską (dez)aktywuje się poprzez lekkie potrząśniecie tabletem? ${ }^{7}$.

Żartobliwą nazwę otrzymał smartfon $\mathrm{z}$ oprogramowaniem dostosowanym do obsługi głosowej osób niewidomych i niedowidzących: SeeYou Phone (2012). To nowatorski pierwszy polski i jeden z nielicznych na świecie projektów pozwalających na bezproblemowe korzystanie z obszernych zasobów smartfona. Zarówno z elementarnych funkcji

${ }^{7}$ Stanford Course Yields Touchscreen Braille Writer, https://www.youtube.com/watch?v=ABfCXJSjAq0. 
użytkowych, takich jak budzik, kalendarz, notatnik, odtwarzacz muzyki, poprzez lupę (zoom), skaner twarzy, kodów kreskowych i obsługę tekstów, po przeglądarkę stron internetowych i portale społecznościowe. Program stworzył młody informatyk Marcin Łapa z myślą o niedowidzącej matce, pomysły konsultując i na bieżąco sprawdzając przy pomocy osób z dysfunkcjami wzroku (w tym niewidomego alpinisty). Szybko powstała wersja komercyjna, wyparta z rynku przez błyskawicznie rozwijające się technologie aplikowane w nowoczesnych smartfonach. Jedną z nich jest aplikacja „Pomocne oko”, wykorzystująca kamerę w telefonie (laptopie, tablecie itp.), dzięki której asystent niewidomego (dyspozytor, dyżurny, wolontariusz) może prowadzić go „krok po kroku” w dowolnej przestrzeni, jako zdalny, interaktywny przewodnik-nawigator. Przedsięwzięcie to, przewidziane jako „bezpłatna usługa społeczna”, sfinansowane zostało z kilku źródeł, w tym środków Fundacji Instytutu Rozwoju Regionalnego oraz Europejskiego Funduszu Społecznego (https://www.pomocneoko.firr.org.pl). Zastąpiono przestarzałe systemy wykorzystujące nawigację GPS, stosowane dotychczas przez osoby niewidome i niedowidzące pragnące zachować samodzielność. To kolejny krok do przodu bez konieczności oparcia jedynie na białej lasce.

Wyższy stopień komplikacji i większe wyzwanie komunikacyjne stanowią binarne deficyty, jak w przypadku osób głuchoniemych. O ile z łatwością osoby te mogą korzystać z telefonów komórkowych na własny użytek, to problemem jest ich komunikacja z innymi ludźmi. Z pomocą przychodzi praktyczny wynalazek ukraińskich studentów EnableTalk, sprzęgający smartfon $\mathrm{z}$ innymi odbiornikami (laptop, tablet) oraz połączonymi bezprzewodowo specjalnymi rękawicami (http://enable-talk.com). Gesty osoby migającej rękawicą połączoną z systemem dekodowane są przez program i odczytywane na głos jako znaki, słowa, zdania. Na genialny w swojej prostocie pomysł wpadł polski nastolatek Mateusz Mach, który jako miłośnik hip-hopu zauważył, że mowa gestów i język ciała twórców tej muzyki wykazuje zaskakująco duże podobieństwa $\mathrm{z}$ uproszczoną wersją języka migowego. Asocjację tę wykorzystał, przyczyniając się do powstania aplikacji Five App (Bellon, 2016) - komunikatora dla głuchych i głuchoniemych, wykorzystującego dotykowe ikony w smartfonie, smartwatchu, tablecie itp. Sekwencje dotykanych ikon składają się na proste frazy i komunikaty czytane przez powszechnie używane elektroniczne urządzenia. Aplikacja jest bezpłatna i możliwa do ściągnięcia z dobrych stron internetowych. Nie wymaga żadnych dodatkowych manipulatorów, rękawic i urządzeń peryferyjnych. Od innych aplikacji podobnego typu wyróżnia ją łatwość obsługi, intuicyjność i prostota. Jest użyteczna tak jak przy korzystaniu z emotikonów lub GIF-ów, których w przeciętnym smartfonie są setki, bardzo przydatnych dla osób nierozpoznających twarzy (Alzheimer, prozopagnozja) i/lub stanów emocjonalnych (autyzm, zespół Aspergera).

Jeszcze wyższy stopień trudności wyznacza komunikacja osób głuchoniewidomych $\mathrm{z}$ otoczeniem. Wydatną pomocą służy alfabet austriackiego filozofa z XIX w. Hieronymusa Lorma, który na skutek choroby stracił słuch i wzrok. By móc kontaktować się z innymi, wymyślił język polegający na dotykaniu poszczególnych części dłoni, na której znajdują się znaki umowne (alfabet punktowy). Każdy moduł dłoni (po obu jej stronach) wraz z palcami stanowi swoisty zbiór znaków (liter i cyfr) tworzących elementarz. Za jego sprawą głuchoniewidoma Helena Keller mogła uczyć się, a następnie studiować 
(Różański, 2020). Język Lorma jest transparentny i intuicyjny; wielu zakochanych bezwiednie odkrywa go, gdy określonym dotykiem i siłą nacisku dłoni pragnie dyskretnie zakomunikować sobie ważne i wrażliwe dla nich treści. Nowoczesna elektronika użytkowa wzbogaca możliwości komunikacyjne związane z językiem Lorma. Do pracy wciągnięto rękawicę Lorma (ang. Mobile Lorm Glove), która będąc nasycona aktywnymi sensorami (reprezentującymi punkty nacisku; „litery”), reaguje na dotyk, a znaki i słowa w ten sposób tworzone, składają się na tekst gromadzony i czytany przez smartfon lub podobne urząazenie. Informacja może biec też w drugą stronę: rękawica przetwarza sms/mail/ chat na odpowiedni nacisk rękawiczki, odczuwalny i czytelny dla głuchoniewidomego. System ten został zaprojektowany przez niemieckich pragmatycznych badaczy (Gollner, Bieling, Joost, 2012). Lorm i Heller stali się niepełnosprawnymi na skutek przebytych chorób, przechodząc wcześniej podstawowe etapy edukacji i pierwotnej socjalizacji. Stopień komplikacji rośnie w sytuacji, gdy człowiek rodzi się głuchoniewidomym i pragnie kontaktować się z innymi, choć dzięki żmudnej edukacji i ta trudność jest pokonywana (Rakowska, 2006). Wiele wyzwań stoi jeszcze przed badaczami zarówno technicznej, jak humanistyczno-społecznej proweniencji.

Odpowiednio dobranymi, dostosowanymi narzędziami komunikacyjnymi można dotrzeć do osób z deficytami fizycznymi i intelektualnymi. Edukacja do pewnego wieku jest w Polsce obowiązkowa i dotyczy chorych i niepełnosprawnych. Dla ludzi dotkniętych czterokończynowym porażeniem mózgowym jest alfabet/język Charlesa Blissa, złożony z pojedynczych znaków, składanych w większe całości, tworzące proste komunikaty i obszerniejsze sensy i znaczenia. Główny bohater instruktywnego filmu Chce się żyć pierwszy trzyznakowy komunikat, jaki składa przy pomocy terapeutki, to: „Ja nie roślina”. Stanowił bolesne nawiązanie do beznadziejnej sytuacji, w jakiej pacjent znajdował się przez prawie 30. lat. Wobec braku jednoznacznego z nim kontaktu, uznawano go za niepełnosprawnego intelektualnie, za „warzywo". Elementarne możliwości komunikacyjne przywróciły mu status człowieka. Nie bez powodu jednym z wyróżników bycia człowiekiem jest intersubiektywna komunikatywność, określana przez antropologów i filozofów jako homo locquens, homo communicativus (Andrzejewski, 2006, 2010). Bolesław Andrzejewski był spiritus movens powstania w 2015 r. na Wydziale Nauk Społecznych UAM Poznań, przy Instytucie Filozofii i z kierunkiem „filozofia” połączonym, nowego kierunku studiów: „komunikacja społeczna”. Kolejnym krokiem jest powstanie na AGH w Krakowie kierunku „informatyka społeczna”, łączącego współczesną wiedzę socjologiczną z nowoczesnymi technologiami komunikacyjnymi.

\section{MULTIMEDIALNE KONSOLE I VIRTUAL REALITY (VD) W NOWOCZESNEJ REHABILITACJI}

Niepełnosprawni fizycznie i intelektualnie wykorzystujący do komunikacji język Blissa posługują się fizycznymi i laserowymi wskaźnikami (umieszczanymi np. na głowie), a same znaki mają postać materialną (karty, plansze). Elektronika użytkowa i urządzenia mobilne przyczyniają się do digitalizacji i cyfryzacji języków, a tym samym większej ich 
plastyczności. Obok języka Blissa przykładem tego jest alfabet/język dr. Seusse’a (Theodora Seussa Geisela), który w barwnej postaci opowiada świat, w pobudzający wyobraźnie sposób łącząc obrazy z dźwiękami. Dziś animowane obrazy/postaci ożywają na ekranach laptopa/smartfonu/tabletu, wydając przy tym stosowne dźwięki. Urządzenia elektroniczne, pomimo braku akceptacji Światowej Organizacji Zdrowia, są powszechnie wykorzystywane przez rodziców, by bawiąc dzieci, uczyły je, bądź uspokajały/usypiały, dając dorosłym chwilę wytchnienia. Współczesne dzieci socjalizację pierwotną przechodzą, ucząc się na smartfonach, laptopach i tabletach. Animacje dostosowane są do wieku rozwojowego dzieci, które coraz częściej, zanim zaczną chodzić i mówić, potrafią biegle obsługiwać urządzenia multimedialne. Ale też dzięki elektronicznym urządzeniom i internetowi możliwa była/jest masowa edukacja zdalna dzieci i młodzieży podczas pandemii COVID-19.

Na korzyść multimedialnych urządzeń należy także poczytać fakt, że z powodzeniem są wykorzystywane jako suplement pełnowartościowej rehabilitacji. Przykładem tego jest zastosowanie do pracy przez zabawę konsol do gier typu Nntendo, Play Station oraz Xbox, które są interaktywne: digitalizując użytkowników, odtwarzają ich postaci i ruchy w czasie rzeczywistym. Innymi słowy, gdy przy pomocy konsoli gra się w tenisa lub jeździ na deskorolce (a także wózku inwalidzkim), to wykonuje się takie same sekwencje ruchów, jak w rzeczywistości. Xbox 360 kinect już od dekady wykorzystywany jest w rehabilitacji pacjentów po amputantacjach, z porażeniem mózgowym, po udarze połowiczym itp., sprzyjając ćwiczeniom priopriocepcji, reedukacji ruchem (Kawka, b.d.). W takich ćwiczeniach chętnie biorą udział zarówno ludzie młodzi, jak i seniorzy. Rehabilitacja taka propagowana jest przez Fundację Iskierka (https://fundacjaiskierka.pl). Jeszcze bardziej obiecujące jest wykorzystanie w rehabilitacji nowoczesnych egzoszkieletów sprzężonych z technologią Virtual Reality (VD). Od 2019 r. system taki stosuje się w poznańskim szpitalu ortopedycznym im. Wiktora Degi do rehabilitacji dzieci i młodzieży z MPD.

\section{ZAKOŃCZENIE}

Podczas pisania tego artykułu trwały gorące protesty przeciwko wyrokowi Trybunału Konstytucyjnego, dotyczącego tzw. „aborcji eugenicznej”. Nie jest to pierwsza manifestacja związana z niepełnosprawnością w ostatnich kilku latach. Wcześniej przed i w budynku Sejmu RP manifestowali opiekunowie osób niepełnosprawnych wraz z podopieczny$\mathrm{mi}$, ratownicy medyczni, pielęgniarki oraz rehabilitanci. Niemiecki filozof Hans Georg Gadamer twierdził, że współczesne problemy dotyczące chorób nieodmiennie wkraczają „na pole napięć społeczno-politycznych” (Gadamer, 2011, s. 7; zob. Giedrojć, 2020). Filozofujący socjolog niemiecki Harald Welzer zauważa: „Nauki społeczne i badania kultury są całkowicie zafiksowane na normalności i ślepe na katastrofy. (...) tak, jakby zjawiska w rodzaju załamywania się społeczeństwa, konfliktu o zasoby, masowych migracji, zagrożeń bezpieczeństwa, lęku, radykalizacji, ekonomii wojny i przemocy i tak dalej, nie podpadały pod ich kompetencje” (za: Bauman, 2010). Zdaniem Welzera: „Katastrofy społeczne odsłaniają kulisy społeczeństwa, ujawniają jego funkcjonalne i dysfunkcjonal- 
ne zależności, które inaczej pozostałyby ukryte; uchylają drzwi pozwalające dojrzeć życie podziemne społeczeństwa i tym samym ukazują, na jakich założeniach co do „normalności” opiera się jego funkcjonowanie. Zdzierają wreszcie zasłonę ze słabości administracji, które występują przecież także wówczas, gdy nikt ich nie sprawdza, i wskazują, że za każdym razem przemoc stanowi dostępną opcję działania" (za: Bauman, 2010).

Naturalne katastrofy są sprawdzianem mocy demokracji i efektywności działania systemów polityczno-społecznych (Leggewie, Welzer, 2012), a gwałtowne reakcje społeczne w sytuacjach nadzwyczajnych przyczyniają się do przełomów i zwrotów w działaniach komunikacyjnych, o jakich pisał filozof i socjolog niemiecki Jürgen Habermas (1981). Badania na bieżąco prowadzone przez poznańskich socjologów podczas pandemii COVID-19 wskazują skrajną ambiwalencję poglądów, postaw i strategii przetrwania ankietowanych (Drozdowski, Frąckowiak, Krajewski, Kubacka, Luczys, Modrzyk, Rura, Stamm, 2020) oraz narracji społecznej toczącej się podczas pierwszej i drugiej fali koronawirusa. Niemiecki socjolog Ulrich Beck był zdania, że współczesny człowiek „musi nauczyć się, pod groźbą kary permanentnego upośledzenia, pojmować samego siebie jako ośrodek działania, jako biuro planistyczne własnej biografii, własnych umiejętności, orientacji, kontaktów partnerskich itd." (Beck, 2002, s. 203). Zdanie to zdaje się idealnie pasować do nowej zwirtualizowanej rzeczywistości społecznej, wymuszającej zastosowanie nowych rozwiązań technologicznych w relacjach interpersonalnych, komunikacyjnych, medycznych i społecznych spowodowanych pandemią COVID-19. 


\section{BIBLIOGRAFIA}

Adams, D. (1994). Autostopem przez galaktykę. Wydawnictwo Zysk i S-ka.

Andrzejewski, B. (2006). Słowo wstępne. Homo Communicativus, 1, 5-6.

Andrzejewski, B. (2010). Poznanie i komunikacja. Szkice z nowożytnej i współczesnej filozofii jezzyka. Wydawnictwo UPK.

Asystent Google vs Google Now - różnice, dostępne funkcje (2019). https://eu.community. samsung.com/t5/aplikacje-mobilne-i-us\%C5\%82ugi/asystent-google-vs-google-nowr\%C3\%B3\%C5\%BCnice-dost\%C4\%99pne-funkcje/td-p/871331

Austin, M.L., Ryan, S.K. (2018). In the blink of an eye: The Story of Mia Austin and her triumph over locked-in syndrome. Xlibris. www.xlibris.com

Bauby, J.D. (1997). Skafander i motyl. Słowo/obraz terytoria.

Bauman, Z. (2010). Panika wśród pasożytów, czyli komu bije dzwon. https://wyborcza.pl/ magazyn/1,124059,8455046,Panika_wsrod_pasozytow_czyli_komu_bije_dzwon.html

Beck, U. (2002). Społeczeństwo ryzyka. W drodze do innej nowoczesności. Wydawnictwo Naukowe Scholar.

Bellon, M. (2016). Mateusz Mach rozwija aplikację Five App. Jest nowa wersja pierwszego na świecie komunikatora dla Głuchych. https://businessinsider.com.pl/firmy/five-appkomunikator-dla-gluchych-tlumacz-jezyka-migowego/kcd079d

CBOS (2019). Sytuacja społeczno-ekonomiczna seniorów. https://cbos.pl/SPISKOM.POL/2019/K_129_19.pdf

Centrum Usług Społecznych (2020). CUS: gdzie i dla kogo? https://www.prezydent.pl/kancelaria/centrum-uslug-spolecznych

Cohen, S. (2009). Folk devils and moral panics. The creation of the Moods and Rockers. Routledge.

Cyfrowi debiutanci. Kursy dla seniorów (2020). https://www.gazetasenior.pl/cyfrowi-debiutanci-kursy-dla-seniorow

Daszkiewicz, M. (2019). Kampanie społeczne o tematyce zdrowotnej - analiza treści i form przekazów komunikacyjnych. W: W. Nowak, K. Szalonka (red.), Zdrowie i style życia: wyzwania ekonomiczne i społeczne (s. 269-298). Wydawnictwo Uniwersytetu Wrocławskiego.

Domagała, A. (2015). Narracja i jej zaburzenia w otępieniu alzheimerowskim. Wydawnictwo UMCS.

Drozdowski, R., Frąckowiak, M., Krajewski, M., Kubacka, M., Luczys, P., Modrzyk, A., Rura, P., Stamm, A. (2020). Życie codzienne w czasach pandemii. http://socjologia.amu. edu.pl/images/pliki/Zycie_codzienne_w_czasach_pandemii._Raport_z_drugiego_etapu_badan_wersja_pe\%C5\%82na.pdf

Earp, B.D. (2020). Prostytucja i niepełnosprawność. W: D. Edmonds (red.), Filozofia kontra świat (s. 122-126). Wydawnictwo Naukowe PWN.

Gadamer, H.G. (2011). O skrytości zdrowia. Media Rodzina.

Gajeta, P. (2019). Ciało wobec techno nauki. Perspektywa trans humanistyczna. Studia Socjologiczne, 1(232), 117-132. https://doi.org/10.24425/sts.2019.126134 
Giedrojć, M. (2020). Niepełnosprawność w Polsce w wymiarze politycznym i społecznym. Analiza wybranych zagadnień. Difin.

Gollner, U., Bieling, T., Joost, G. (2012). Mobile Lorm Glove: introducing a communication device for deaf-blind people. https://www.researchgate.net/publication/221308576_Mobile_Lorm_Glove_introducing_a_communication_device_for_deaf-blind_people

Goode, E., Ben-Yehuda, N. (2009). Moral panics. The social construction of deviance. Willey Blackwell.

Grandin, T., Moore, D. (2017). Kochaj i pomóż dorosnąć. Jak pomóc dziecku ze spektrum autyzmu wejść $w$ dorosłe życie. Wydawnictwo Uniwersytetu Jagiellońskiego.

Grandin, T., Panek, R. (2016). Mózg autystyczny. Podróż w głąb niezwykłych umysłów. Copernicus Center Press.

Grass, Ł. (2019). Szlag mnie trafił. Są w życiu rzeczy, o które warto walczyć do końca. Ringier Axel Springer.

Grice, P.H. (1989). Studies in the way of words. Harvard University Press.

Gumowska, A. (2020). Seks w wielkich miastach. Wydawnictwo Literackie.

GUS (2014). Sytuacja demograficzna osób starszych i konsekwencje starzenia się ludności Polski w świetle prognozy na lata 2014-2050. https://stat.gov.pl/obszary-tematyczne/ ludnosc/ludnosc/sytuacja-demograficzna-osob-starszych-i-konsekwencje-starzenia-sieludnosci-polski-w-swietle-prognozy-na-lata-2014-2050,18,1.html

GUS (2020). Sytuacja osób starszych w Polsce w 2018 roku. https://stat.gov.pl/obszary-tematyczne/osoby-starsze/osoby-starsze/sytuacja-osob-starszych-w-polsce-w-2018-ro$\mathrm{ku}, 2,1 . \mathrm{html}$

Habermas, J. (1981). Theorie des kommunikativen Handelns. Suhrkamp Verlag.

Heller, J., Vogel, S. (2003). Nic śmiesznego. Wydawnictwo Muza.

Izdebski, Z., Wiśniewski, J.L. (2014). Intymnie. Rozmowy nie tylko o miłości. Wydawnictwo Znak.

Kaufman, M., Silverberg, C., Odette, F. (2013). Pełnosprawni! Uniwersalny przewodnik po seksie. Wydawnictwo Czarna Owca.

Kawka, D. (b.d.). Jak wykorzystać konsolę Xbox Kinect w rehabilitacji? https://rehabilitacjabielsko.pl/blog/jak-wykorzystac-konsole-xbox-kinect-w-rehabilitacji.

Kijak, R.J. (2013). Seksualność, niepełnosprawność, rzeczywistość. Wspótczesne konteksty badawcze w problematyce seksualności człowieka z niepełnosprawnością. Instytut Rozwoju Służb Społecznych.

Kowalik, S. (2018). Stosowana psychologia rehabilitacji. Wydawnictwo Naukowe Scholar.

Krupińska, D. (2014). Robot dla chorych na alzheimera. Wynalazek naukowców z lubelskiego Uniwersytetu Medycznego. https://kurierlubelski.pl/robot-dla-chorych-na-alzheimera-wy nalazek-naukowcow-z-lubelskiego-uniwersytetu-medycznego/ar/3604581

Lane, H. (2006). Construction of deafness. W: L.J. Davis (red.), The Disability Studies Reader (s. 79-92). Routledge.

Leggewie, C., Welzer, H. (2012). Koniec świata jaki znaliśmy: klimat, przyszłość i szanse demokracji. Wydawnictwo Krytyki Politycznej. 
Lindquist, U. (2006). Wiosłować bez wioseł. Książka o życiu i śmierci. Jacek Santorski \& Co Agencja Wydawnicza.

Mamzer, H., Isański, J. (2018). Socjologia kultury w czasach inteligentnych zwierząt i uczacych się maszyn. Wydawnictwo Epigram.

Marsh, R., Hudson, J. (2015). Dowód życia. Wydawnictwo WAM.

McAndrew, F.T., Koehnke, S.S. (2016). On the Nature of Creepiness. New Ideas in Psychology, 43, 10-15. https://doi.org/10.1016/j.newideapsych.2016.03.003

Międzynarodowa Klasyfikacja Chorób ICD-11 (2018). Addictive behaviours: Gaming disorder (2018). https://www.who.int/news-room/q-a-detail/addictive-behaviours-gaming-disorder

Mikołajewska, E., Mikołajewski, D. (2013). Możliwości automatyzacji i robotyzacji otoczenia osoby niepełnosprawnej. Niepełnosprawność. Zagadnienia - problemy - rozwiązania, 2(7), 107-126.

Narodowy Program Szczepień przeciw COVID-19 (2020). https://www.gov.pl/web/szczepimysie/narodowy-program-szczepien-przeciw-covid-19

Naskręt, A. (2019). Uwięziony krzyk. Warszawskie Wydawnictwo Literackie Muza.

Nawrocka, J. (2013). Społeczne doświadczenie starości. Stereotypy, postawy, wybory. Oficyna Wydawnicza Impuls.

Nicholas, S., O’Malley, T. (red.) (2018). Moral Panics, social fear, and the media; historical perspectives. Routledge Taylor \& Francis Group.

Niedbalski, J. (2019). Niepełnosprawność i osoby z niepetnosprawnościa. Od pasywności i wykluczenia do aktywności życiowej i integracji społecznej. Wydawnictwo Uniwersytetu Łódzkiego.

Niepełnosprawność i technologia (2018). Kultura Współczesna. Teoria. Interpretacje. Prakty$k a$ [numer tematyczny], 3(102).

NIK (2016), NIK o dostosowaniu stron internetowych do potrzeb osób z niepełnosprawnościami. https://www.nik.gov.pl/aktualnosci/nik-o-dostosowaniu-stron-internetowych-dopotrzeb-osob-z-niepelnosprawnosciami.html

O co pytali seniorzy ekspertów TeleRady we wrześniu (2020). My 60+. Magazyn mieszkańców Wielkopolski w najlepszym wieku, 4(53), 5.

Okupnik, M. (2018). W niewoli ciała. Doświadczenie utraty zdrowia i jego reprezentacje. Wydawnictwo Universitas.

Opiat-Bojarska, J. (2011). Kto wyłączy mój mózg. Wydawnictwo Zysk i S-ka.

Ostrowska, A. (red.) (2007). O seksualności osób niepełnosprawnych. Instytut Rozwoju Służb Społecznych.

Pajączkowski, P. (2016). Warto żyć. Wydawnictwo Poznańskie.

Pezdek, K. (2016). Biomedyczny i społeczny model niepełnosprawności w perspektywie filozoficznej. Kultura i Społeczeństwo, 3, 3-11. https://doi.org/10.35757/KiS.2016.60.3.1

Piątek, K. (2015). Kampanie społeczne jako narzędzia zmiany postaw wobec osób z niepełnosprawnością. Media i Społeczeństwo, 5, 136-149. 
Porayska-Pomsta, K. (2018). ECHOES Project. https://www.ucl.ac.uk/ioe/research-projects/2020/sep/echoes-project

Program „Usługi społeczne dla mieszkańców Poznania” (2017). https://www.larche.org.pl/ wrpo

Przegalińska, A. (2016). Istoty wirtualne. Jak fenomenologia zmieniała sztuczna inteligencję. Wydawnictwo Universitas.

Przegalińska, A., Oksanowicz, P. (2020). Sztuczna inteligencja. Nieludzka, arcyludzka. Społeczny Instytut Wydawniczy Znak.

Rakowska, A. (2006). Język, komunikacja, niepełnosprawność. Wybrane zagadnienia. Wydawnictwo Naukowe Akademii Pedagogicznej.

Rosicka-Jaczyńska, K. (2011). Ołówek. Wydawnictwo Poligraf.

Różański, M. (2020). Helena Keller. Kobieta, która zmieniła świat. Międzynarodowy Tydzień Wiedzy o Osobach Głuchoniewidomych. http://www.niepelnosprawni.pl/ledge/x/1101170

Sahaj, T. (2018). Physical Activity, Disability and Health in Advertising Campaigns Associated with Major Sporting Events in the World. Przegląd Socjologii Jakościowej, 14(3), 72-91. http://dx.doi.org/10.18778/1733-8069.14.3.05

Sahaj, T. (2021). Marginalizowane grupy społeczne w kontekście kultury fizycznej i sportu. Wydawnictwo AWF.

Salmed (2018). https://wcpit.pl/pl/news/salmed-2018,1136

Salon, A. (2015). Sprawozdanie z I. Ogólnopolskiej Konferencji Naukowej z cyklu Sens i bezsens starości pt. „Niepełnosprawność i starość w wymiarze poznawania, przeżywania i percepcji społecznej”. Ekslibris Biblioteka Gerontologii Społecznej, 2(10), 165-166.

Sałwacka, S. (2020). Dla kogo pulsometry? Gazeta Wyborcza - Tygodnik Poznań.

SeeYou Phone (2012). Seeyou - telefon dla niewidomych. https://mobtech.interia.pl/smartfony/news-seeyou-telefon-dla-niewidomych,nId,714479

Skura, M. (2016). Ja-inny. Relacje społeczne osób z niepełnosprawnością. Wydawnictwo Uniwersytetu Warszawskiego.

Sokołowski, M. (red.) (2013). Nowe media i wyzwania współczesności. Wydawnictwo Adam Marszałek.

Stefaniak-Hrycko, A. (2012). Starość w reklamie telewizyjnej - śmieszy czy przeraża? Nowiny Lekarskie, 81(1), 89-95. https://jms.ump.edu.pl/uploads/2012/1/89_1_81_2012.pdf

Ślebioda, A. (2013). Stigmatized by the Language - Linguistic Labels of the Disabled People in Poland and the United States. Journal of Education Culture and Society, 2, 404-412. https://doi.org/10.15503/jecs20132.404.412

Świtaj, J. (2008). 12 oddechów na minutę. Wydawnictwo Otwarte.

Tammet, D. (2010). Urodziłem się pewnego błękitnego dnia. Pamiętnik nadzwyczajnego umysłu z zespołem Aspergera. Wydawnictwo Czarne.

Tokarczuk, O. (2020). Prace Hermesa, czyli jak tłumacze codziennie ratują świat.

W: O. Tokarczuk, Czuły narrator (73-92). Wydawnictwo Literackie.

Vujicic, N. (2012). Bez nóg, bez rąk, bez ograniczeń. Wydawnictwo Aetos. 
Walter, N. (2007). Nowe media dla niewidomych i słabo widzacych. Wydawnictwo Naukowe UAM.

Wdrażamy program Domowej Opieki Medycznej. Pulsoksymetr będzie monitorował stan zdrowia pacjentów w domu (2020). https://www.gov.pl/web/koronawirus/wdrazamy-program-domowej-opieki-medycznej-pulsoksymetr-bedzie-monitorowal-stan-zdrowia-pa cjentow-w-domu

Wittgenstein, L. (2012). Tractatus logico-philosophicus. Wydawnictwo Naukowe PWN.

Wolffers, I., Beelen, N. van (2003). Public health and the human rights of sex workers. Lancet, 361(9373), 1981. https://doi.org/10.1016/S0140-6736(03)13594-5

Zimbardo, P.G., Coulombe, N.S. (2015). Gdzie ci mężczyźni? Wydawnictwo Naukowe PWN.

Żarnowska-Mazur, A. (2015). Cyfrowy świat seniora. Aktywnie w Internecie. Wydawnictwo Naukowe PWN.

Żarnowska-Mazur, A. (2015a). Cyfrowy świat seniora. Smartfon, tablet i nie tylko. Wydawnictwo Naukowe PWN.

Żarnowska-Mazur, A. (2016). Cyfrowy świat seniora. Bezpiecznie w Internecie. Wydawnictwo Naukowe PWN.

Żuchowska-Skiba, D. (2020). Wpływ języka na poczucie wykluczenia osób z niepełnosprawnościami. Socjolingwistyka, 34, 77-91. https://doi.org/10.17651/SOCJOLING.34.5

\section{ŹRÓDŁA INTERNETOWE}

http://assistech.eu/pl

http://enable-talk.com

http://my60plus.pl

http://www.intendix.com

http://www.mowik.pl

http://www.pzszach.org.pl

http://www.rejestrwad.pl

https://fundacjaiskierka.pl

https://migam.org/pl

https://nowymarketing.pl

https://pacjent.gov.pl

https://pzgomaz.com

https://secondlife.com

https://socialwifi.com/pl

https://uprp.gov.pl

https://wspierajseniora.pl

https://www.braingate.org 
https://www.gov.pl

https://www.hackathon.com

https://www.ipon

https://www.pomocneoko.firr.org.pl

https://www.who.int

www.cdt.pl

\section{MATERIAŁY MULTIMEDIALNE. FILMY FABULARNE I SERIALE}

A.I. Sztuczna inteligencja, 2001, ang. Artificial Intelligence: AI, reż. S. Spielberg.

Alita. Battle Angel, 2019, reż. R. Rodriguez.

Autostopem przez Galaktykę, 2005, ang. The Hitchhiker's Guide to the Galaxy, reż. G. Jennings.

Avatar, 2009, reż. J. Cameron.

Blade Runner 2049, 2017, reż. D. Villeneuve.

Chce się żyć, 2013, reż. M. Pieprzyca.

Detektyw Monk, 2002-2009.

Doktor House, 2004-2012.

Down the road. Zespół w trasie, 2020-2021.

Dziewczyna w sieci pająka, 2018, ang. The Girl in the Spider's Web, reż. F. Alvarez.

Dziewczyna z tatuażem, 2011, ang. The Girl with the Dragon Tattoo, reż. D. Fincher.

Ex Machina, 2017, reż. A. Garland.

The Good Doctor, 2017-2021.

Gwiazd naszych wina, 2014, ang. The Fault in Our Stars, reż. J. Boone.

Gwiezdne wojny, 1977, ang. Star Wars, reż. G. Lucas.

Ja, robot, 2004, ang. I, Robot, reż. A. Proyas.

Kolekcjoner kości, 1999, ang. The Bone Collector, reż. P. Noyce.

Łowca androidów, 1982, ang. Blade Runner, reż. R. Scott.

Ponad wszystko, 2017, ang. Everything, Everything, reż. S. Meghie.

Sala samobójców, 2011, reż. J. Komasa.

Sanatorium miłości, 2019-2020.

Skafander i motyl, 2007, fr. Le scaphandre et le papillon, reż. J. Schnabel.

Surogaci, 2009, ang. Surogates, reż. J. Mostow.

Trzy kroki od siebie, 2019, ang. Five Feet Apart, reż. J. Baldoni.

Trzy minuty. 21:37, 2010, reż. M. Ślesicki.

Uzdrowisko, 2020.

Wychowane przez wilki, 2020, ang. Raised by Wolves, reż. R. Scott, L. Scott, A. Gabassi. 